\title{
Bacterial contamination in kitchens of rural and urban areas in Meerut district of Utter Pradesh (India)
}

\author{
Pankaj K. Tyagi ${ }^{1 *}$ and Shruti Tyagi ${ }^{2}$ \\ ${ }^{1}$ Department of Biotechnology, Meerut Institute of Engineering and Technology, Meerut Uttar Pradesh, India. \\ ${ }^{2}$ Department of Biotechnology, Meerut Institute of Engineering and Technology, Meerut Uttar Pradesh, India.
}

Accepted 26 April, 2013

\begin{abstract}
A total of $\mathbf{8 0}$ samples were collected from kitchens of rural and urban areas in Meerut district during July to August 2010. The more bacterial contamination (97.5\%) in kitchens of rural areas as compared to the kitchen of urban areas $(80 \%)$ was reported. The total number of bacteria isolates from the air of kitchens in rural and urban areas was 69 and 52, respectively, with total number of bacterial strain (66). The numbers of bacterial genera identified in kitchens of rural areas are 13 and in kitchen of urban areas are 10. The present investigation indicates that the rural kitchens are more contaminated (with the dominating 7 genera of pathogenic virulent bacteria that is, Proteus, Salmonella, Shigella, Aeromonas, Enterobacter, Citrobacter and Klebsiella species) as compared to urban kitchens (3 pathogenic genera such as Acinetobacter, Streptococcus and Corynebacterium species). In rural kitchens, the bacterial growth on the basis of colonies forming plates Proteus spp. for $70 \%$ of isolates, followed by Salmonella spp. (63\%), Shigella spp. (55\%), E. coli (50\%), Klebsiella spp. (47.5\%), Staphylococcus spp. (45\%), Micrococcus spp. (38\%), Bacillus spp. (30\%), Lactobacillus spp. (12.5\%), Lactococcus spp. (10\%), Aeromonas spp. (7.5\%), Citrobacter spp. (5\%), Enterobacter spp. (2.5\%) and urban kitchens; Micrococcus spp. accounted for $65 \%$ of isolates, followed by Bacillus spp. (60\%), Staphylococcus spp. (50\%), E. coli (40\%), Acinetobacter (30\%), Pseudomonas spp. (20\%), Lactobacillus spp. (18\%), Paenibacillus spp. (12.5\%), Corynebacterium spp. (10\%) that was observed. The primary sources of this bacterial contamination in kitchens are the food spoilage, stored kitchen waste and vegetables.
\end{abstract}

Key words: Bacterial contamination, pathogenic bacteria genus, non-pathogenic bacteria genus, rural kitchens vs. urban kitchens.

\section{INTRODUCTION}

In recent years, there has been increasing concern about indoor air quality in kitchens, living rooms, bed rooms and its surrounding areas. The family home can sometimes become a source of microbial contamination, where molds and bacteria proliferate. Inadequate ventilation and high moisture levels resulting from water damage episodes or excess humidity often cause the proliferation of fungi (molds) and bacteria on visible surfaces or hidden inside structures. In such a context, a good diagnosis of the degree of microbial contamination in homes becomes more important. Unfortunately, assess-ment tools are few and insufficient. On the other hand, surface samples are useful to document the nature of visible microbial contamination. In many human activities, micro-organisms in the environment represent a hidden but dangerous risk factor. Concern has increased with the introduction of advanced technologies in hospitals, industry and agriculture. In recent years, many studies have been carried out on this topic, and nowadays the evaluation of the level of air microbial contamination in places at risk is considered 
to be a basic step toward prevention. In the home, odors caused by microorganisms may be troublesome in carpets and curtains. These organisms cause odors, defacement, and deterioration of carpets and curtains. Many of these microorganisms are associated with allergic reactions and potentially infectious diseases (Anderson, 1969, Anderson et al., 1982). A study conducted in Saudi Arabia on prosthetic and surface-covering materials found Pseudomonas aerugi-nosa, E. coli and Staphylococcus aureus contaminated floor carpets. Carpets had significantly higher bacterial count than many other floors covering material (Bahannan and Abdel-Salam, 2002). Domestic and industrial kit-chens are the most important focuses of attention for infection. In such environments, cross-contamination is the responsible factor for diseases spread by food (Teixeira et al., 2007). The number of food borne disease out-breaks due to bacteria has increased in recent years. Several potential causes of these outbreaks include storage temperature, inadequate thermal treatment, cross contamination, poor hygiene conditions of processing facilities and contaminated food contact surfaces (Cogan et al., 2002; Devere and Purchase, 2007). Kitchen sponges offer an ideal place for harmful bacteria and other pathogens such as viruses to grow. Some of these pathogens include E. coli, Salmonella, Klebsiella pneumoniae and Enterobacter cloacae (Ikawa and Rossen, 1999). Pathogenic organisms continuously enter the home with foods (food borne) or through water (waterborne), through foods prepared in the home by an infected person (person to person spread), through the air (airborne) by the insects or via pets (Beumer et al., 1999). Food borne diseases associated with foods prepared in contaminated kitchen include salmonella as the most common culprit (Holah and Thorpe, 1990; Dufrenne et al., 2001; Kusumaningrum et al., 2004). Some other bacterial infections associated with contaminated kitchen environment are caused by Campylobacter, Listeria, Staphylococcus aureus, Bacillus cereus and E. coli (Dufrenne et al., 2001; Regnath et al., 2004).

The present research work revealed that the status of air of kitchens in rural and urban areas and to check the contamination with a variety of bacterial contaminations. In India, especially Utter Pradesh states of India republic have very few literatures that have been identified of bacterial contamination in the air of kitchens in rural and urban areas and their comparison. This study therefore aimed to investigate, identify and comparison of the bacterial contamination in air of kitchens of 80 different samples from 80 kitchens in rural and urban areas of Meerut district.

\section{MATERIALS AND METHODS}

\section{Collection of samples}

Randomly selected of 80 samples ( 40 kitchen of each in rural and urban areas) were collected from July to August 2010 in Meerut district of Utter Pradesh (India).

\section{Methodology}

All samples of air of kitchens were aseptically collected in already clean prepared culture plates of nutrient agar medium. The samples were taking from the open air from kitchens. Nutrient Agar Plate (NA) was used for the collection of samples. For sample collections, NA plates were placed on the different locations in kitchens, left open for 1 to $2 \mathrm{~h}$, and then incubated for $24 \mathrm{~h}$ at 28 to $30^{\circ} \mathrm{C}$. Pure culture was prepared by sub culturing 2 to 3 times in nutrient medium. Nutrient broths were also used for further biochemical characterization.

\section{Sample analysis and identification of microbes}

All samples were analyzed by conventional techniques as described by Buchanan and Gibbons (1974) and Carter and Cole (1995). After collection of samples, culture plates were incubated in incubator at 28 to $30^{\circ} \mathrm{C}$ for $24 \mathrm{~h}$. After 24 to $48 \mathrm{~h}$ of incubation, the colonies that appeared visually dissimilar were chosen, counted and subculture to fresh nutrient agar and incubated at $37^{\circ} \mathrm{C}$ for $24 \mathrm{~h}$. Identification of microorganisms did not commence until it was evident that a pure culture had been obtained. Colonies identifiable as discrete on the different agar medium (EMB, Blood Agar, Macconky Agar, Xylose lysine deoxycholate Agar etc) was carefully examined macroscopically for culture characteristics such as the shape, color, size texture and hemolytic reactions. Colonies are Gram stained and individual bacterial cells were observed under the microscope. The bacteria were speciated using these isolated colonies (Beumer et al., 1996). Further identification of the entire organisms was done using the different taxonomical standard methods. Anaerobes and many traditional morphological and biochemical test were selected for this study.

\section{RESULTS}

A total of 80 samples from 80 kitchens (40 each samples of rural and urban kitchens, respectively) were collected and analyzed for bacterial contamination and their comparisons. Sample obtained from rural and urban kitchens from near dustbins, sink, washing-up areas, food shelf, cutlery and crockery, refrigerator, vegetables racks, floor, back side of door and near gas cylinder. The higher positive bacterial growth $97.5 \%$ in kitchens of rural areas and $80 \%$ in the kitchen of urban areas is observed. On the basis of primary characterization, the samples were subjected to morphological and biochemical analysis to confirm the identified bacteria. The presence of bacteria was discerned in 71 samples of air of kitchens in rural and urban areas out of 80 samples. Only 9 samples (one in rural and eight in urban areas) of air of kitchens were found to be bereft of bacteria. The total number of bacteria isolates from the air of kitchens in rural and urban areas was 69 and 52 respectively, with 66 bacterial strains. The numbers of bacterial genus identified in kitchens of rural areas are 13 and in kitchen of urban areas are 10 (Table 1). In rural kitchens, the 35 bacterial strains was found in which the Proteus spp. (7) and Salmonella spp. (5) contributed the major fraction of bacteria followed by Shigella spp. and Klebsiellaspp. (4), E. coliand Micrococcus 
Table 1. Bacterial analysis in the air of 80 samples collected from kitchens in rural and urban (40 each) Meerut district of Utter Pradesh.

\begin{tabular}{|c|c|c|c|c|c|c|}
\hline Type of sample & $\begin{array}{l}\text { Name of ample } \\
\text { collections site }\end{array}$ & $\begin{array}{c}\text { Total Number of } \\
\text { samples processed }\end{array}$ & $\begin{array}{l}\text { Number of samples } \\
\text { devoid of bacteria }\end{array}$ & $\begin{array}{l}\text { Total Number of } \\
\text { bacteria isolated }\end{array}$ & $\begin{array}{c}\text { Number of } \\
\text { genus isolated }\end{array}$ & $\begin{array}{l}\text { Bacteria } \\
\text { identified }\end{array}$ \\
\hline \multirow{4}{*}{ Kitchens of rural } & Jainpur & 10 & $\mathrm{Nil}$ & 18 & 5 & (1) \\
\hline & Rithani & 10 & Nil & 20 & 8 & (2) \\
\hline & Maharolly & 10 & 1 & 14 & 9 & (3) \\
\hline & Rijhani & 10 & Nil & 17 & 7 & (4) \\
\hline \multirow{4}{*}{ Kitchens of Urban } & Maliyana & 10 & Nil & 17 & 6 & (5) \\
\hline & Madhopuram & 10 & 1 & 15 & 4 & (6) \\
\hline & Modipuram & 10 & 2 & 12 & 6 & (7) \\
\hline & Shastri nagar & 10 & 5 & 08 & 4 & (8) \\
\hline
\end{tabular}

Kitchens of rural households: (1) Staphylococcus spp., Proteus spp.: 2 strains, Salmonella spp.: 2 strains, E. coli, Shigella spp.; (2) Bacillus spp., Klebsiella spp., Salmonella spp., Proteus spp., Lactococcus spp., Aeromonas spp., Micrococcus spp., Lactobacillus spp.; (3) Bacillus spp., Klebsiella spp.: 2 strain, Micrococcus spp., Staphylococcus ssp., Salmonella spp., Proteus spp.:2 strain, E. coli, Enterobacter spp., Shigella spp.; (4) Klebsiella spp., Micrococcus spp., Shigella spp.: 2 strain, E. coli, Bacillus spp., Citrobacter spp., Proteus spp.: 2 strain.

Kitchens of urban households: (5) Staphylococcus spp.: 2 strains, Micrococcus spp.: 2 strains, Corynebacterium spp., Acinetobacter spp.: 2 strains, Pseudomonas spp., Bacillus spp.; (6) Micrococcus spp.: 2 strains, Bacillus spp.: 3 strains, E. coli, Lactobacillus spp.; (7) Acinetobacter spp.: 2 strains, Streptococcus spp.: 2 strains, Pseudomonas spp, Bacillus spp., E. coli; (8)Staphylococcus spp.: 2 strains, Micrococcus spp.: 3 strains, E. coli, Paenibacillus spp.

spp. (3), Bacillus spp. and Staphylococcus spp. (2), Lactococcus spp., Aeromonas spp., Lactobacillus spp., Enterobacter spp. and Citrobacter spp. (01). However, in urban kitchens, the 31 bacterial strain was observed in which the Micrococcus spp. (7) and Bacillus spp. (5) contributed the major fractions of bacteria followed by Acinetobacter spp. and Staphylococcus spp. (4), E. coli (3), Streptococcus spp. and Pseudomonas spp. (2), Lactobacillus spp., Klebsiella spp., Paenibacillus spp. and Corynebacterium spp. (1). It is a notable fact that the more pathogenic bacterial genus 7 such as Proteus, Salmonella, Shigella, Aeromonas, Enterobacter, Citrobacter and Klebsiella spp., were found only in the kitchens of rural areas with 6 non-pathogenic genus such as E. coli, Bacillus spp., Micrococcus spp., Staphylococcus spp., Lactococcus spp., and Lactobacillus spp., On the other hand, the only 3 pathogenic bacterial genus such as Acinetobacter, Strepto- coccus and Corynebacterium spp. were found in the kitchens of urban areas with 7 non-pathogenic bacterial genus Pseudomonas spp., Paenibacillus spp., Bacillus spp., Micrococcus spp., E. coli, Lactobacillus spp. and Staphylococcus spp. The bacterial growth on the basis of colonies forming plates in rural kitchens are observed in Proteus spp. for $70 \%$ of isolates (28 colony types from 40 plates), followed by Salmonella spp. (63\%), Shigella spp. (55\%), E. coli (50\%), Klebsiella spp. (47.5\%), Staphylococcus spp. (45\%), Micrococcus spp. (38\%), Bacillus spp. (30\%), Lactobacillus spp. (12.5\%), Lactococcus spp. (10\%), Aeromonas spp. (7.5\%), Citrobacter spp. (5\%) and Enterobacter spp. (2.5\%).

In urban kitchens, Micrococcus spp. accounted for $65 \%$ of isolates (26 colony types from 40 plates), followed by Bacillus spp. (60\%), Staphylococcus spp. (50\%), E. coli (40\%), Acinetobacter (30\%), Pseudomonas spp. (20\%), Lactobacillus spp. (18\%), Paenibacillus spp. (12.5\%) and Corynebacterium spp. (10\%) are observed in urban kitchens (Table 2). The present result shows that the bacteria isolated from air of kitchens in rural areas are more pathogenic and virulent $(7$ bacterial genus of pathogenic bacteria) and shows higher pathogenic activity as compared to the bacteria isolated from air of the kitchens in urban areas (3 bacterial genera of pathogenic bacteria). The morphological identification of the bacteria isolated from air of kitchens based on agar slant culture characteristic and preliminary characterization are given in Table 3, in which the morphological characteristics such as shape, size, colour, texture and hemolytic growth helped to identify the bacteria. Some preliminary characters such as motility, gram positive, gram negative and growth in broth media also helped to identify the bacteria genus. The biochemical characterization based on 12 different tests such as Catalase test, Oxidase 
Table 2. Morphological identification based on Agar Slant Culture (NA medium) characteristics and number of colonies of the bacteria isolated from the air of kitchens in rural and urban areas.

\begin{tabular}{|c|c|c|c|c|}
\hline Source & Bacterial genus & $\begin{array}{c}\text { Colonies (\%)/ } \\
40 \text { samples }\end{array}$ & $\begin{array}{c}\text { Nature of } \\
\text { bacteria }-/+^{*}\end{array}$ & Morphological identification characters \\
\hline \multirow{13}{*}{ Rural } & Staphylococcus spp. & $18(45 \%)$ & - & Abundant, opaque, golden growth \\
\hline & Bacillus spp. & $13(30 \%)$ & - & Abundant, opaque, white waxy growth \\
\hline & Micrococcus spp. & $15(38 \%)$ & - & Soft, smooth, yellow growth \\
\hline & Lactobacillus spp. & $05(12.5 \%)$ & - & White, irregular, big circular \\
\hline & E. coli & $20(50 \%)$ & - & White, moist, glistening \\
\hline & Lactococcus spp. & $04(10 \%)$ & - & Circular, white, regular \\
\hline & Klebsiella spp. & $19(47.5 \%)$ & + & Slimy, White, translucent, raised growth \\
\hline & Salmonella spp. & $25(62.5 \%)$ & + & Thin, even, grayish growth \\
\hline & Shigella spp. & $22(55 \%)$ & + & Thin, even, grayish growth \\
\hline & Aeromonas spp. & $3(7.5 \%)$ & + & White, circular, thin, pin drop like growth \\
\hline & Proteus spp. & $28(70 \%)$ & + & Thin, blue-gray, spreading growth \\
\hline & Enterobacter spp. & $01(2.5 \%)$ & + & Rough, thin, slimy, raised growth \\
\hline & Citrobacter spp. & $02(5 \%)$ & + & Rough, irregular, even growth \\
\hline \multirow{10}{*}{ Urban } & Pseudomonas spp. & $08(20 \%)$ & - & Abundant thin, White growth, media truing green \\
\hline & Paenibacillus spp. & $05(12.5 \%)$ & - & Whitish, grayish, slightly transparent, glistening \\
\hline & Staphylococcus spp. & $20(50 \%)$ & - & Abundant, opaque, golden growth \\
\hline & Bacillus spp. & $24(60 \%)$ & - & Abundant, opaque, white waxy growth \\
\hline & Micrococcus spp. & $26(65 \%)$ & - & Soft, smooth, yellow growth \\
\hline & Lactobacillus spp. & $06(15 \%)$ & - & White, irregular, big circular \\
\hline & E. coli & $16(40 \%)$ & - & White, moist, glistening \\
\hline & Corynebacterium spp. & $04(10 \%)$ & + & Thin, white, smooth, regular \\
\hline & Streptococcus spp. & $04(10 \%)$ & + & Thin, even, white growth \\
\hline & Acinetobacter spp. & $12(30 \%)$ & + & Rough surface growth, paper like \\
\hline
\end{tabular}

*(-) Non pathogenic bacterial genes, (+) Pathogenic bacterial genes.

test, H2S Production test, Nitrate reduction test, Indole Production test, MR reaction, VP reaction, Citrate utilizetion test, Urease test, Lactose Fermentation, Sucrose Fermentation and Dextrose Fermentation for both gram positive and gram negative strains in the total number of 66 bacterial strains in kitchens are illustrated in Figure 1.

\section{DISCUSSION}

Domestic kitchen environment are potential places for harboring and spreading pathogenic bacteria including Pseudomonas aeruginosa, K. pneumonia, Bacillus spp., Diptheroids, E. cloacae and Staphylococcus epidermidis. According to Borneff et al. (1985, 1989), Kusmaningrum et al. (2002) and Tumwine et al. (2003), these pathogens survive on surfaces for hours or days, depending on the species. They also stated that wiping of surfaces (physiccal removal) tends to transfer and spread microorganisms from one surface to the other (Ojima et al., 2002a). Bacteria are readily spread from cloths and sponges during wiping (Cogan et al., 2002; Ojima et al., 2002b; Gorman et al., 2002). Pseudomonas spp., an opportunistic pathogen causes UTI, respiratory tract infection, der- matitis, soft tissue infection and joint infection, gastrointestinal infections and a variety of systemic infections. Pseudomonas spp. can also be found in household drains of showers and kitchens (Regnath et al., 2004). Its prediction to moist environment makes it more possible to exist in kitchen surfaces, dust beans and used sponges. Once infection with pseudomonas is established; it is hard to control since this organism is frequently resistant to many commonly used antibiotics (Qarah, 2006; Humphrey et al., 2001). Corynebacterium spp. (coryneform) have been in the focus of attention in recent years since cases of osteomyleitis, cerebrospinal meningitis, endocarditis, bacteremia, urinary tract infection and liver abscess were associated with this agent (Mickucka et al., 1997).

Studies of the domestic environment by Finch et al. (1978), Scott et al. (1982), Speirs et al. (1995), Josephson et al. (1997) and Rusin et al. (1998) indicate that micro-organisms, including some potentially pathogenic species, are commonly found in all areas of the home environment. The results of these studies indicate that wet sites such as kitchen sink areas (particularly sink surfaces, draining board, U-tubes), toilets and nappy buckets are most commonly associated with heavy conta- 
Table 3. Preliminary characterization of bacterial strains based on different morphological and physiological parameters.

\begin{tabular}{lc}
\hline Preliminary characterization parameters & Number of bacterial strains of kitchens of rural and urban (66) \\
\hline Motility & 30 \\
Gram (+) & 31 \\
Gram (-) & 35 \\
Mac Conkey agar & 35 \\
Shape & 21 round, 45 rod \\
Anaerobic Growth & 47 \\
Oxidative fermentation & 62 \\
Acid production by Glucose & 44 \\
\hline
\end{tabular}

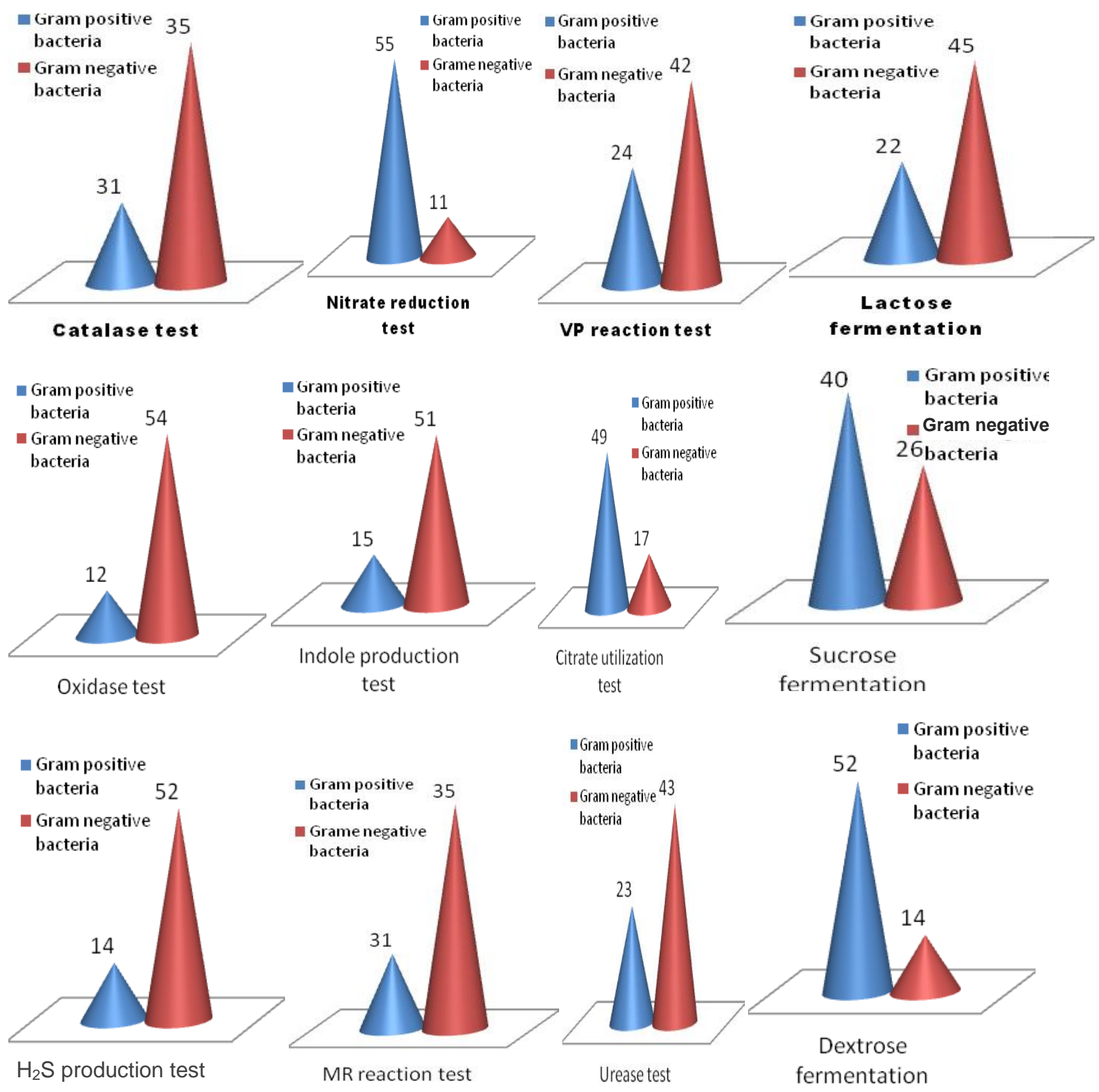

Figure 1. Bacterial sample analysis of different biochemical test collected from air of kitchens of rural and urban areas. 
mination and the occurrence of potentially harmful species. The Enterobacteriacae spp. isolated in the study of Scott et al. (1982) included Klebsiella, Enterobacter, Citrobacter, Proteus and E. coli. A similar pattern was also reported in the studies of Finch et al. (1978) and Speirs et al. (1995). B. subtilis, Bacillus spp and Bacillus polymyxa has been used in animals feed, baking, cleaning and waste water, food and beverage because of its capability to produce alpha amylase, crackerase and neutral protease that works at higher $\mathrm{pH}$ and temperature range that relaxes dough to get uniform crackers and improve cracker flavors (www.bio-cat.com). However, in the preparation of this enzyme needs inactivation of the sporulating capacity of $B$. subtilis using high pressurized conditions (Vasantha et al., 1983). S. epidermidis has become the most important cause of nosocomial infections in recent years. Its pathogenicity is mainly due to the ability to form biofilm on indwelling medical devices. In a biofilm, S. epidermidis is protected against attacks from the immune system and against antibiotic treatment, making $S$. epidermidis infections difficult to eradicate (Vuong and Otto, 2002). S. aureus is ubiquitous and may be a part of human flora, however, the organism may cause disease through invasion and toxin production such as abscess, pneumonia, diarrhea and the most feared toxic shock syndrome (Tolan, 2007). K. pneumonia can cause pneumonia, septicemia, wound infection, burn infection, urinary track infection and ankylosing spondylitis. Like Pseudomonas, it is an opportunistic pathogen. Pneumonia caused by Klebsiella spp. has around $50 \%$ mortality due to the underlying disease but may reach $90 \%$ in untreated cases (Umeh and Berkowitz, 2006). Bacterial contamination in kitchen spread out through sponges and washcloths use normally in kitchens were similarly reported (Alwakeel, 2007).

The present results insuring the results of previous studies of bacterial contamination in kitchens of Panipat district of Haryana (Tyagi et al., 2011) in which villages kitchens are more contaminated with bacterial infection as compared to urban kitchens and bacterial contamination spread out from kitchens to other surrounding areas. The primary sources of these bacteria are kitchens in which the food spoilage and stored dust bean content for many days and directly entered vegetables (some infected with higher pathogens). After getting favorable condition, these bacteria spread out kitchens to its surrounded areas which are more suitable for growth. Avoiding this bacterial contamination to make possible arrangements, in kitchen, and its surrounding areas such as floor carpeting in homes should be minimized or avoided since this serve as habitats for opportunistic infection agents that posses harm to one's health, proper ventilation and sanitation in kitchens, washing sponges renewable should be dried after use or immersed in boiling water for 5 to $10 \mathrm{~min}$. Furthermore, hygienic measures and precaution in the kitchens should be well maintained to reduce harmful bacteria levels. Vegetables are entered in the kitchen after proper washing and checking for infection. The kitchens of rural and urban areas like dustbins, sink, washing-up areas etc. should specially be cleaned up weekly or regularly by disinfectants.

Hence, the better quality of air can be achieved by manipulating sanitation and hygiene within kitchens and its surrounded areas.

\section{ACKNOWLEDGEMENTS}

Authors are highly thankful to Dr. Tejpal Singh Dewa, Head, Department of Microbiology, Dolphin Institute, Dehradun for providing laboratory facilities to identify some bacteria. Authors are also highly thankful to Revivers of African Journal of Microbial Research for his valuable comments to strengthen this research article.

\section{REFERENCES}

Alwakeel SS (2007). Bacterial and Aspergillus spp. contamination of domestic kitchens in Riyadh, Saudi Arabia. Saudi J. Biol. Sci. 14(1):16.

Anderson RL (1969). Biological evaluation of carpeting. Appl. Microbiol.18 (I2):180-187.

Anderson RL, Mackel DC, Stoler BS, Mallison GF (1982). Carpeting in hospitals: an epidemiological evaluation.' J. Clin. Microbiol. 15(3) 408-415.

Bahannan SA, Abdel-Salam MM (2002). An in-vitro study of the effects of various disinfectants on prosthetic and surface materials. Saudi. Med. J. 23(4): 396-399.

Beumer R, Bloomfield SF, Exner M, Fara GM, Scott E (1999). The need for home hygiene policy and guidelines on home hygiene. Ann Ig, 11: 11-26.

Borneff J, Witting JR, Borneff M, Hartmetz G (1985). Occurrence of enteritis- causing agents in private households- pilots study. Zentralbl Bacterial Mikrobiol. 18 (2-3): 319-34.

Borneff J (1989). 'Efficient hygiene precautions in the household today.' Zentralbl Bakteriol Mikrobiol. Hyg B. 187(4-6):404-13

Buchanan RE, Gibbons NE (1974). Bergey's manual of determinative bacteriology. 8th ed. Williams and Wilkins Co. Baltimore, p. 1246.

Carter GR, Cole JR (1995). Diagnostic procedures in veterinary bacteriology and mycology. 6th ed. pp. 457-467. Academic Press Inc. California.

Cogan TA, Slader J, Bloomfield SF, Humphrey TJ (2002). Achieving hygiene in the domestic kitchen: the effectiveness of commonly used cleaning procedures. J. Appl. Microbiol. 92: 885-92.

Devere E, Purchase D (2007). Effectiveness of domestic antibacterial products in decontaminating food contact surfaces. Food Microbiol. 24(4): 425-430.

Dufrene J, Ritmeester WE, Asch ED, van Leusden F, de Jonge R (2001). Quantification of the contamination of chicken and chicken products in the Netherlands with salmonella and campylobacter.' J. Food Prot. 64: 538-541.

Finch JE, Prince J, Hawksworth M (1978). A bacteriological survey of the domestic environments. J. Appl. Bacteriol. 45(3):357-64.

Gorman R, Bloomfield S, Adley CC (2002). A study of cross contamination of food borne pathogens in the domestic kitchen in the Republic of Ireland. Int. J. Food Microbiol. 76 (1-2): 143-50.

Holah JT, Thorpe $\mathrm{RH}$ (1990). 'Cleanability in relation to bacterial retention on unused and abraded domestic sink materials'. J. Appl. Bacteriol. 69: 599-608.

Humphrey TJ, Martin KW, Slader J, Durham K (2001). Campylobacter spp. in the kitchen: spread and persistence. J. Appl. Microbiol. (30): 115S-120S.

Ikawa JY, Rossen JS (1999). Reducing bacteria in household sponges. J. Environ. Health, 62:18-22.

Josephson KL, Rubino JR, Pepper IL (1997). Characterization and 
quantification of bacterial pathogens and indicator organisms in household kitchens with and without the use of a disinfectant cleaner. J. Appl. Microbiol. 83:737-50.

Kusumaningrum HD, van Asselt ED, Beumer RR, Zwietering $\mathrm{MH}$ (2004). A quantitative analysis of cross-contamination of Salmonella and Campylobacter spp. via domestic kitchen surfaces. J. Food Prot. 67(9): 1892-903.

Kusumaningrum HD, van Putten MM, Rombouts FM, Beumer RR (2002). Effects of antibacterial dishwashing liquid on foodborne pathogens and competitive microorganisms in kitchen sponges. J. Food Prot. 65(1): 61-65.

Mickucka A, Gospodarek E, Bialek M (1997). Opportunistic infections with coryneform, Med. Sci. Monitor, 3(2):154-157.

Ojima M (2002a). 'Bacterial contamination of Japanese households and related concern about sanitation'. Environ. Health Res. 12(1): 41-52.

Ojima M (2002b). 'Hygiene measures considering actual distributions of microorganisms in Japanese households'. J. Appl. Microbiol. 93 (5): 800-809.

Qarah S (2006). 'Paeudomonas infections'. www.emedicine.com.

Regnath T, Kreutzberger M, Illing S, Oehme R, Liesenfeld O (2004). Prevalence of Pseudomonas aeruginosa in households of patient with cystic fibrosis. Int. J. Hyg. Environ. Health, 207 (6): 585-588.

Rusin P, Orosz-Coughlin P, Gerba C (1998). Reduction of fecal coliform, coliform and heterotrophic plate counts bacteria in the household kitchen and bathroom by disinfection with hypochlorite cleaners. J. Appl. Microbiol. 85(9): 819-828.

Scott E, Bloomfield SF, Barlow CG (1982). An investigation of microbial contamination in the home. J. Hyg. Cambridge, 89: 79-293.

Speirs JP, Anderton A, Anderson JG (1995). A study of the microbial content of the domestic kitchen. Int. J. Environ. Health Res. 5 (2):109-122.
Teixeira P (2007). Note: colonisation of bench covers materials by Salmonella Typhimurium. Food Sci. Technol. 13(1): 5-10.

Tolan RW (2007). Staphylococcus aureus infection. www.emedicine.com

Tumwine J, Thompson J, Katui-Katua M, Mujwahuzi M, Johnstone N, Porras I (2003). Sanitation and hygiene in urban and rural households in East Africa'. Int. J. Environ. Health Res. 13(2): 107-15.

Tyagi PK, Tyagi S, Kumar R, Panday CS (2011). Bacteriological contamination of air of kitchens in rural and urban areas of Panipat District in Haryana (India). Int. J. Pharm. Biol. Sci. 2(1): B247-B-256.

Umeh O, Berkowitz LB (2006). Klebsiella infections, www.emedicine.com.

Vasantha NB, Uratani RF, Ramaley F, Freese E (1983). Isolation of a developmental gene of Facillus subtilis and its expression in Escherichia coli. Proc. Natl, Acad. Sci. USA, 80(3): 785-789.

Vuoong C, Otto M (2002). Staphylococcus epidermidis infections. Microbes. Infect. 4(4): 481-489. 